\title{
Starch extracted from pineapple (Ananas comosus) plant stem as a source for amino acids production
}

\author{
Pei Hsia Chu' ${ }^{1}$, Mohd Azwan Jenol', Lai Yee Phang ${ }^{1}$, Mohamad Faizal Ibrahim', Sehanat Prasongsuk², \\ Wichanee Bankeeree ${ }^{2}$, Hunsa Punnapayak², Pongtharin Lotrakul ${ }^{2}$ and Suraini Abd-Aziz ${ }^{1 *}$ (D
}

\begin{abstract}
Background: Pineapple plant (Ananas comosus) is one of the largest productions in Asia and its increasing production has generated a huge amount of pineapple wastes. Pineapple plant stem is made up of high concentration of starch which can potentially be converted into value-added products, including amino acids. Due to the increasing demand in animal feed grade amino acids, especially for methionine and lysine, the utilisation of cheap and renewable source is deemed to be an essential approach. This study aimed to produce amino acids from pineapple plant stem hydrolysates through microbial fermentation by Pediococcus acidilactici Kp10. Dextrozyme was used for hydrolysis of starch and Celluclast $1.5 \mathrm{~L}$ for saccharification of cellulosic materials in pineapple plant stem.

Results: The hydrolysates obtained were used in the fermentation to produce methionine and lysine. Pineapple plant stem showed high starch content of $77.78 \%$. Lignocellulosic composition of pineapple plant stem consisted of $46.15 \%$ hemicellulose, $31.86 \%$ cellulose, and $18.60 \%$ lignin. Saccharification of alkaline-treated pineapple plant stem gave lower reducing sugars of $13.28 \mathrm{~g} / \mathrm{L}$ as compared to untreated, where $18.56 \mathrm{~g} / \mathrm{L}$ reducing sugars obtained. Therefore, the untreated pineapple plant stem was selected for further process. Starch hydrolysis produced $57.57 \mathrm{~g} / \mathrm{L}$ reducing sugar (100\% hydrolysis yield) and saccharification of cellulosic materials produced $24.67 \mathrm{~g} / \mathrm{L}$ reducing sugars (56.93\% hydrolysis yield). The starch-based and cellulosic-based of pineapple plant stem were subjected as carbon source in methionine and lysine production by P. acidilactici Kp10.
\end{abstract}

Conclusions: In conclusion, higher methionine and lysine production were produced from starch-based hydrolysis ( $40.25 \mathrm{mg} / \mathrm{L}$ and $0.97 \mathrm{~g} / \mathrm{L}$, respectively) as compared to cellulosic-based saccharification ( $37.31 \mathrm{mg} / \mathrm{L}$ and $0.84 \mathrm{~g} / \mathrm{L}$, respectively) of pineapple plant stem.

Keyword: Pineapple plant, Stem, Starch, Amino acids, Methionine, Lysine

\section{Background}

In food basis, fruits and vegetables are considered as the highest wastage rate produced, which accounted approximately $50 \%$ globally, including pineapple industry sector. The pineapple, Ananas comosus, is a tropical plant and

\footnotetext{
*Correspondence: suraini@upm.edu.my; suraini.aziz@gmail.com 1 Department of Bioprocess Technology, Faculty of Biotechnology and Biomolecular Sciences, Universiti Putra Malaysia, 43400 Serdang, Selangor, Malaysia

Full list of author information is available at the end of the article
}

most economically significant plant in the Bromeliaceae family. Increasing pineapple production leads to massive amount of waste products generated from the industry, as they were disposed in landfills or burnt for energy production and these might pollute the environment if not handled properly $[1,2]$. Nearly, one-third of the pineapple plant is lost or wasted, which accounts for approximately 1.3 billion metric tonnes [3]. In fact, pineapple is considered the most favoured of all tropical fruits and it is a prominent ingredient in fruit and juice products, including jams, juice concentrates, essence, jellies, squash, and 
pickles. By weight basis, approximately $55 \%$ of total pineapple parts are discarded mainly due to the transportation and storage purposes [4]. The by-products generated from pineapple industry not only involved food processing industry, but also enzyme industry as the plant can be employed for bromelain extraction [5]. In plantation area, numerous amount of waste has been generated during pruning, harvesting as well as post-harvesting, which includes leaves and plant stem core. Malaysia, known as one of the largest producers in Asia, has certainly generated metric tonnes of pineapple wastes or by-products, which can potentially be used as a feedstock for the production of value-added products.

In relation to the concepts of the sustainable development and integrated environmental protection, the renewable raw materials, such as waste, should be utilised in bioconversion of value-added products as its costeffective process as well as zero waste generation [6]. This measure is able to provide the customers both ecological and economic benefits. In fact, in food, proteins are vital components, which composed of the 20 proteinogenic amino acids. In this point of view, the animal synthesises their own specific amino acid spectrum which generally the essential amino acids (methionine, lysine, and threonine) presence in limiting amount in crude feeds. Clearly, methionine and lysine are considerably ecological importance to meat producing industry due to the essential role of feed in transformation into animal protein.

Starch is the most abundant molecule on earth after cellulose and the major carbohydrate reserve in plants. Starch is a major energy source on earth, providing up to $80 \%$ of the calories consumed by humans [7]. Starch is a carbohydrate extracted from agricultural raw materials which is widely present in literally thousands of everyday food and non-food applications. Starch is a so-called green alternative material and is a most promising candidate for future use [8] due to its low cost, availability from renewable resources, and broad-ranged capability in food and non-food products. Basically, starch is a carbohydrate material that exists naturally as granules. Starch granules are normally found in seeds, roots, tubers, stems, and leaves. Demand for native starches increased globally, as it can minimise the use of chemically modified starches. Native starches have many applications in the food industry, pharmaceutical industry, paper making industry, cosmetics industry, etc. The starch industry separates the components of the plant: starch, protein, cellulose envelope, soluble fractions, and others, such as lignocellulosic material, as found in pineapple plant stem or basal stem (Fig. 1). However, the methods of manufacture are specific to each plant and the industrial tools are normally dedicated to a raw material. Starch is usually used in its native form, where it was extracted from raw

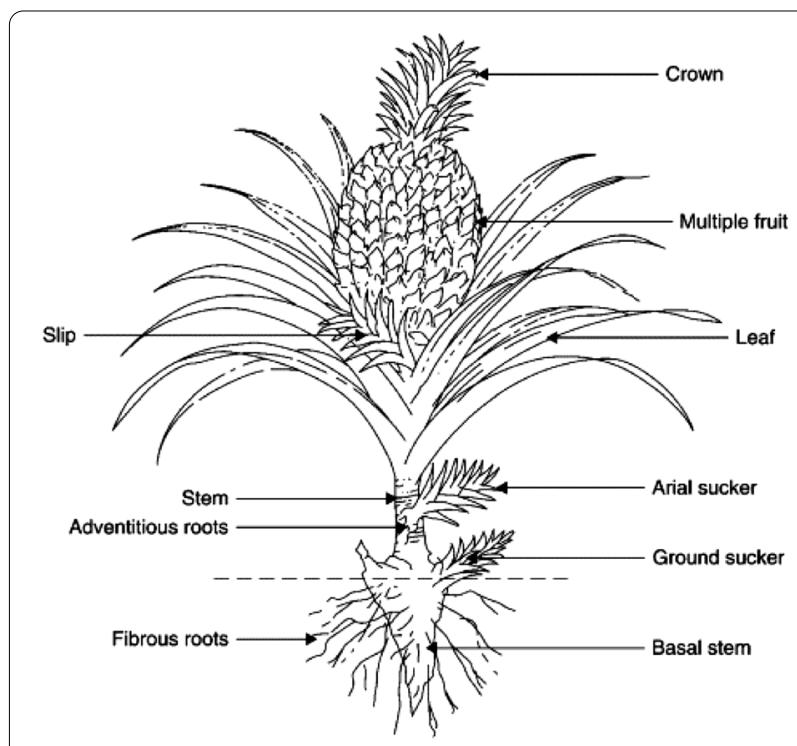

Fig. 1 Morphological structure of pineapple plant. ( Source: Hassan et al. [80])

materials in its purest form. However, modifications on the native starch, termed modified starch, can be carried out to obtain certain properties or better characteristics of the starch, either through physical, chemical, enzymatic or genetic modifications [9].

Methionine is a proteinogenic amino acid, best known for its role in the initiation of translation. It possesses an unbranched, hydrophobic side chain and it is the only amino acid that contains a thioether (i.e., $\mathrm{C}-\mathrm{S}-\mathrm{C}$ bonding). Methionine is widely used as a feed additive in the poultry, swine and fish farming industries. It is produced as a racemic mixture from petrochemical feedstocks, with global production capacities in the hundreds of thousands of tonnes per annum [10]. While, L-lysine is known to be an essential amino acid in animal as well as human nutrition. On the other hand, it is beneficial as chemical agent, food materials, feed additive, and medicament. The efforts in the production of these amino acids through microbial fermentation have been conducted in several studies. As reported by Ezemba et al. [11], a total of $2.06 \mathrm{mg} / \mathrm{mL}$ of methionine has been produced from plaintain-starch hydrolysate/groundnut meal. On the other note, Sgobba et al. [12] have investigated the synergy effect of synthetic Escherichia coli-Corynebacterium glutamicum consortia for the production of L-lysine. As a result, $0.4 \mathrm{~g} / \mathrm{L}$ of lysine has successfully been produced using commercial starch as carbon source. These situations indicated the possibility of pineapple stem, which contained high amount of starch content, to be an alternative feedstock in production of lysine and methionine using microbial fermentation. 
The utilisation of pineapple plant stem as alternative starch supply made it possible for the conversion of waste into wealth. This study aimed to produce amino acids from pineapple plant stem hydrolysates through microbial fermentation by Pediococcus acidilactici Kp10. Dextrozyme was used for hydrolysis of starch and Celluclast $1.5 \mathrm{~L}$ for saccharification of cellulosic materials in pineapple plant stem.

\section{Materials and methods}

\section{Sample collection and preparation}

Pineapple plants stems were collected from AlafPutra Biowealth Sdn Bhd pineapple plantation, Kulai, Johor, Malaysia. The cross-sectional image of pineapple plant stem is shown in Fig. 2. The leaves were removed from pineapple plants stems and the plants stems were chopped into small pieces before they were washed with tap water. The plant stems were then subjected to drying process at $60^{\circ} \mathrm{C}$ for $24 \mathrm{~h}$. The dried pineapple plant stems were ground and kept at room temperature for further use.

\section{Pretreatment of pineapple plant stem}

Pretreatment of pineapple plants stems was carried out based on the method described by Umikalsom et al. [13]. A $5 \%(w / v)$ pineapple plant stem was soaked in $2 \%$ sodium hydroxide solution for $4 \mathrm{~h}$ before autoclaved at $121^{\circ} \mathrm{C}$ for $5 \mathrm{~min}$. The autoclaved sample was washed with distilled water until no alkaline was detected. It was then dried in the oven at $60^{\circ} \mathrm{C}$ for $24 \mathrm{~h}$, subsequently stored at room temperature for further experiment.

\section{Enzymatic hydrolysis of starch and saccharification of cellulosic materials in pineapple plant stem Hydrolysis of starch into fermentable sugar}

Enzymatic hydrolysis of starch present in pineapple plant stem was carried out based on the method described by Awg-Adeni et al. [14]. A 7\% (w/v) dried pineapple plant stem was added into Erlenmeyer flask containing 0.1 M

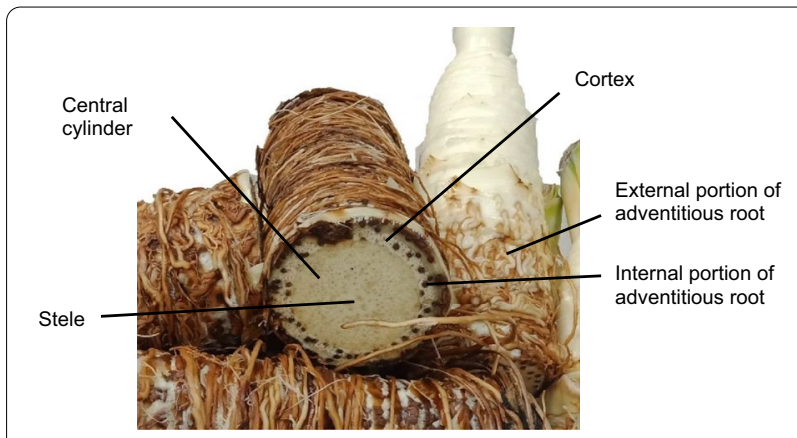

Fig. 2 Cross-sectional image of pineapple plant stem acetate buffer solution at $\mathrm{pH} 4.2$. It was gelatinised by boiling at $100{ }^{\circ} \mathrm{C}$ for $15 \mathrm{~min}$ using a water bath before it was cooled down to $60^{\circ} \mathrm{C}$. The hydrolysis was conducted by adding $5.56 \mathrm{U} / \mathrm{mL}$ Dextrozyme DX $1.5 \mathrm{X}$ (Novozymes, Denmark) with glucoamylase activity of $31.55 \mathrm{U} /$ $\mathrm{mL}$ in the hydrolysis flask. The mixture was stirred continuously and the temperature was maintained at $60{ }^{\circ} \mathrm{C}$ for $60 \mathrm{~min}$. After the hydrolysis process, it was allowed to cool down to room temperature. The sugars solution was centrifuged using Heraeus Multifuge X3R Centrifuge (Thermo Fisher Scientific, Germany) at $4{ }^{\circ} \mathrm{C}$ and $3000 \times \mathrm{g}$ for $10 \mathrm{~min}$ followed by filtration using $1.2 \mu \mathrm{m}$ of Whatman glass microfibre filter attached to a vacuum pump. The recovered sugar, namely, pineapple plant stem hydrolysate, was analysed for reducing sugar and glucose concentration and stored at $4{ }^{\circ} \mathrm{C}$ before the fermentation process. The solid residue was collected and dried in the oven at $60{ }^{\circ} \mathrm{C}$ overnight for further saccharification process. The hydrolysis yield was calculated, as shown in Eq. 1 [14].

$$
\begin{aligned}
& \text { Hydrolysisyield(\%) } \\
& \qquad=\frac{\text { Amount of reducing sugar produced }(\mathrm{g}) \times 0.9 \times 100 \%}{(\text { Starch }(\%) \times \text { Amount of substrate used }(\mathrm{g}))}
\end{aligned}
$$

A correction error of 0.9 was used in the calculation of the number of polysaccharides hydrolysed, because hydrolysis of polysaccharides involves water and $1 \mathrm{~mol}$ of water is required for $1 \mathrm{~mol}$ of reducing sugar released.

\section{Saccharification of cellulosic components into fermentable sugars}

Fermentable sugars were obtained from saccharification using Celluclast 1.5 L (Novozymes, Denmark) based on the method described by Linggang et al. [15]. The saccharification was carried out in $100 \mathrm{~mL}$ working volume using $250 \mathrm{~mL}$ shake flask. A $100 \mathrm{~mL}$ of $0.05 \mathrm{M}$ acetate buffer at $\mathrm{pH} 4.8$ was added to a $5 \%(\mathrm{w} / \mathrm{v})$ of the solid residues obtained from prior hydrolysis. A 10 FPU Celluclast $1.5 \mathrm{~L}$ with the initial activity of $14.63 \mathrm{FPU}$ was added into the saccharification flask. It was then incubated in a shaker incubator (Labwit, China) at $50{ }^{\circ} \mathrm{C}$, with an agitation speed of $200 \mathrm{rpm}$ for $96 \mathrm{~h}$. The sugars solution was filtered using $1.2 \mu \mathrm{m}$ of Whatman glass microfibre filter attached to a vacuum pump. The hydrolysate was analysed for reducing sugar and glucose concentration and stored at $4{ }^{\circ} \mathrm{C}$ before the fermentation process. The hydrolysis yield was calculated, as shown in Eq. 2 [15]: 


$$
\text { Hydrolysisyield }(\%)=\frac{\text { Amount of reducing sugar produced }(\mathrm{g} / \mathrm{L}) \times 0.9 \times 100 \%}{\text { Amount of substrate used }(\mathrm{g} / \mathrm{L}) \times \text { Potential sugars }(\%)}
$$

where potential sugars are the total percentage of hemicellulose and cellulose.

A correction error of 0.9 was used in the calculation of the number of polysaccharides hydrolysed, because hydrolysis of polysaccharides involves water and $1 \mathrm{~mol}$ of water is required for $1 \mathrm{~mol}$ of reducing sugar released.

\section{Amino acids production from pineapple plant stem hydrolysates \\ Medium preparation}

MRS (de Man, Rogosa and Sharpe) medium used for amino acid production using $P$. acidilactici Kp10 based on Toe et al. [16].

\section{Inoculum preparation}

P. acidilactici $\mathrm{Kp} 10$ employed for amino acids production in this study was obtained from the culture collection of Professor Dr Arbakariya Ariff [17] from Department of Bioprocess Technology, Faculty of Biotechnology and Biomolecular Sciences, Universiti Putra Malaysia. The inoculum was prepared based on the method explained by Toe et al. [16]. Prior to use, the stock culture was revived by inoculating the culture into a centrifuge tube containing $1 \mathrm{~mL}$ de Man, Rogosa and Sharpe (MRS) broth. The mixture was let to sit for $15 \mathrm{~min}$ and $500 \mu \mathrm{L}$ was transferred into MRS agar plate for initial colonyforming unit determination and another $500 \mu \mathrm{L}$ was transferred into MRS broth to be incubated in shaker incubator (Labwit, China) at $37^{\circ} \mathrm{C}$ for $24 \mathrm{~h}$. The inoculum with MRS broth was kept in an incubator with agitation speed $100 \mathrm{rpm}$. Then, $1 \%(\mathrm{v} / \mathrm{v})$ of the $24 \mathrm{~h}$ culture was transferred into another $100 \mathrm{~mL}$ MRS broth. The broth was incubated at $37{ }^{\circ} \mathrm{C}$ for $24 \mathrm{~h}$ at $100 \mathrm{rpm}$. Subculture was done until the bacteria was stable enough to enter the fermentation process.

\section{Shake flask fermentation}

Fermentation of P. acidilactici Kp10 was done based on the method described by Toe et al. [16]. A volume of $10 \%$ $(\mathrm{v} / \mathrm{v})$ active 12-h culture with an initial colony-forming unit of $1.82 \times 10^{7}$ CFUs $/ \mathrm{ml}$ was inoculated into $250 \mathrm{~mL}$ shake flask containing $100 \mathrm{~mL}$ MRS medium. The $\mathrm{pH}$ of the fermentation medium was controlled by buffer system using phosphate buffer. The flasks were incubated in a shaker incubator (Labwit, China) at $37{ }^{\circ} \mathrm{C}$ and agitated at $100 \mathrm{rpm}$ for $24 \mathrm{~h}$. The sampling was done in triplicates at a 1-h interval. Three types of medium with different carbon sources were used as the production medium for the fermentation of $P$. acidilactici Kp10. MRS broth using commercial glucose as carbon source was used as a control in the fermentation process. Other MRS medium used pineapple plant stem hydrolysates from starch and cellulosic materials as the carbon source for amino acids production.

\section{Analytical analysis}

All the chemical compositional analyses were done using standard method. All analyses were done in triplicates. The starch content was determined based on the method by Nakamura et al. [18] with slight modification of absorbance at $580 \mathrm{~nm}$. While, the method used in the determination of lignin, hemicellulose and cellulose content of the sample was modified based on the method reported by Iwamoto et al. [19]. The hydrolysates obtained from the hydrolysis and saccharification process were subjected to simple sugars determination using High-Performance Liquid Chromatography (HPLC) based on method explained by Linggang et al. [15]. A Rezex RPM-Monosaccharide $\mathrm{Pb}^{+2}$ column and RI detector were used. The mobile phase was deionised water at a flow rate of $0.6 \mathrm{~mL} / \mathrm{min}$. The analysis was performed at $80{ }^{\circ} \mathrm{C}$. Standard solutions were prepared by dissolving appropriate masses of glucose and xylose in deionised water. The retention times of glucose and xylose were $15.42 \mathrm{~min}$ and $16.96 \mathrm{~min}$, respectively.

The glucoamylase activity of Dextrozyme was determined based on the method described by Leaes et al. [20]. The FPU enzyme activity for Celluclast $1.5 \mathrm{~L}$ was determined using NREL standardised filter paper assay as stated by Tsai and Meyer [21]. Viable bacterial counts were determined by colony-forming method based on the method by Paulino et al. [22] at $37^{\circ} \mathrm{C}$ for $24 \mathrm{~h}$. The pellet of the sample was analysed for cell concentration using optical density method based on the method proposed by Toe et al. [16]. The samples from the fermentation process were centrifuged at $10,000 \mathrm{rpm}(9,300$ rcf) for 5 min using a microcentrifuge (5415 D, Eppendorf). The supernatant containing methionine and lysine (Sigma-Aldrich, Switzerland) was filtered using a $0.22 \mu \mathrm{m}$ of nylon driven filter into a clean Eppendorf tube. The filtered sample was kept at $-20^{\circ} \mathrm{C}$ prior to HPLC analysis. The mobile phases were sonicated using a Thermo-6D Ultrasonic Cleaner (Thermoline, Australia). The determination of methionine and lysine was based on the modified method proposed by Toe et al. [16]. Amino acid yield 
and productivity were calculated, as shown in Eq. 3 and Eq. 4, respectively: on a dry weight basis, which accounted for the lowest percentage as compared to other components in the

$$
\text { Aminoacidyield }(\mathrm{g} / \mathrm{g})=\frac{\text { Concentration of amino acid produced }(\mathrm{g} / \mathrm{L})}{\text { Substrate consumed at respected time }(\mathrm{g} / \mathrm{L})}
$$

$$
\text { Amino acid productivity }(\mathrm{g} / \mathrm{L} / \mathrm{h})=\frac{\text { Concentration of amino acid produced }(\mathrm{g} / \mathrm{L})}{\text { Incubation time }(\mathrm{h})}
$$

\section{Results and discussion}

\section{Chemical compositions of pineapple plant stem}

Pineapple plant stem is biomass with great potential to produce sugar from the extraction of starch and cellulosic materials, which can be used as a carbon source for the production of other products, such as amino acids. Table 1 shows chemical compositions of pineapple plant stem used in this study. The moisture content of pineapple plant stem showed a high percentage at $(75.84 \pm 0.24) \%$, which was almost similar to the moisture content present in pineapple shell and core as reported by Cordenunsi et al. [23]. Nakthong et al. [8] also reported a high value of moisture content in pineapple plant stem at $70 \%$ moisture. Reduction in moisture content helps in increasing the stability and shelf life of the sample, as well as facilitates its storage [24, 25]. Kiharason et al. [26] reported that drying will increase the dry matter and nutrient content of the sample and oven-dried is the most suitable method, because less nutrient was lost due to the fast rate of drying. Total ash is crucial in the quality determination of a biomass, since it accounts for the total minerals of the biomass [27]. Ash content of pineapple plant stem obtained from this study was $0.40 \%$ of the sample

Table 1 Chemical composition of pineapple plant stem

\begin{tabular}{lll}
\hline & This study & [3] \\
\hline Chemical composition $^{\mathrm{a}}$ & & \\
Moisture & $75.84 \pm 0.24$ & 8.78 \\
Dry matter & $24.16 \pm 0.24$ & 89.50 \\
Crude fibre & $8.05 \pm 1.20$ & 37.63 \\
Crude protein & 11.56 & 2.30 \\
Total nitrogen & 1.85 & 0.37 \\
Crude fat & $1.53 \pm 1.09$ & 2.71 \\
Ash & $0.40 \pm 0.00$ & 1.24 \\
Starch & $77.78 \pm 0.02$ & n.d \\
Cellulose & $31.86 \pm 6.34$ & $48-67$ \\
Hemicellulose & $46.15 \pm 0.27$ & $12-24$ \\
Lignin & $18.60 \pm 3.41$ & $20-24$ \\
\hline
\end{tabular}

${ }^{a}$ The chemical composition analysis was based on dry basis, except moisture was based on wet basis sample. The low value of ash obtained indicated that pineapple plant stem contained a low proportion of minerals and inorganic residue. Based on Table 1, the ash percentage was slightly lower compared to pineapple shell in Perola variety, which has a value of $0.53 \%$ as reported by Cordenunsi et al. [23]. The difference in percentage of ash found in pineapple plant stem might be affected by the varieties of pineapple plant used, maturity of the plant, and part of pineapple plant stem used for the determination [28-30].

In this study, the nitrogen content of the pineapple plant stem was recorded at $1.85 \%$. This result was in agreement with the nitrogen content of pineapple plant stem reported by Hanafi et al. [31], where the pineapple plant stem of Moris and Gandul pineapple plant was reported at $1.55 \%$ and $1.63 \%$, respectively. Since the underground part of pineapple plant stem was used in this study, the nitrogen content obtained might be affected by the nitrogen content in soil and the plant cultivars. Crude protein consists of true protein and nonprotein nitrogen, where nitrogen accounts for $16 \%$ of all biological proteins on average. In this study, pineapple plant stem contained as much as $11.56 \%$ crude protein, which was even higher than the result obtained by Zainuddin et al. [3], where Moris pineapple leaves have a crude protein of $7.05 \%$. The amount of crude protein can vary according to the stage of plant growth as well as the parts of the plant [32]. The protein content and composition can also be affected by environmental conditions and nutrients availability in soils, especially nitrogen fertilisation and the strategy of its application [33]. Crude fat content in pineapple plant stem measures the estimation of total fat content, including triacylglycerides, alcohols, waxes, terpenes, steroids, pigments, esters, aldehydes, and other lipids [3]. The crude fat content in the pineapple plant stem used in this study was recorded at $1.53 \%$ on a dry weight basis. As the primary components of biomass, carbohydrates are the most potential biomass component in a biorefinery process, since it acts as storage polysaccharides (starch) or structural polysaccharides (cellulose, hemicelluloses, pectin, and chitin) [34]. Pineapple plant stem used in this study has 
reported a carbohydrate value of $9.91 \%$ on a dry weight basis, which indicated that it consisted of quite a number of sugars and starch; thus, it is a potential biomass to be used in the production of value-added products, such as amino acids.

Pineapple plant stem consisted of high starch and cellulosic content, which made it great potential biomass. The starch content was $77.78 \%$ on a dry weight basis. Nakthong et al. [8] reported a starch content of $97.77 \%$, with amylose content $34.37 \%(\mathrm{w} / \mathrm{w})$ of the whole sample. The percentage of starch content in this study was the highest in pineapple plant stem as compared to other chemical compositions. This result was in line with the statement reported by Sanewski et al. [35], which stated that the stele of pineapple plant stem mainly consists of compact parenchyma with an abundant of the starch present. Thus, pineapple plant stem was expected to be potential starch-based biomass for amino acids production due to the high level of starch present, which can then be converted into fermentable sugars, mainly glucose, through enzymatic hydrolysis.

Gelatinisation was done before starch determination to break down the intermolecular association between amylose and amylopectin at solid state with heating [36]. During heating in water, the starch present in the pineapple plant stem undergoes a transition process, where the starch granules swell and eventually break down into a mixture of polymers-in-solution, making the starch suspension viscous [37]. This process changes the semi-crystalline phase of amylose and amylopectin to an amorphous phase [38]. Thus, the ratio of amylose and amylopectin present in the starch can affect the gelatinisation temperature and properties [39]. The value of lignin, hemicellulose and cellulose of pineapple plant stem were recorded at $18.60 \%, 46.15 \%$, and $31.86 \%$, respectively. Sodium chlorite treatment was used in the removal of lignin to determine the holocellulose content of the biomass. The holocellulose was then allowed to undergo alkali treatment using potassium hydroxide to further remove the hemicellulose content in the pineapple plant stem [19]. The cellulose content of the pineapple plant stem was determined as the residue after complete removal of lignin and hemicellulose. The lignin content obtained in this study was comparable with the results obtained in pineapple leaves and pineapple plant stems as reported by Zainuddin et al. [3]. The aforementioned author also claimed that plant maturation and parts of the plant used will affect the lignin content of the sample, in which the rigidity of the pineapple plant stem also contributes to the high lignin content.

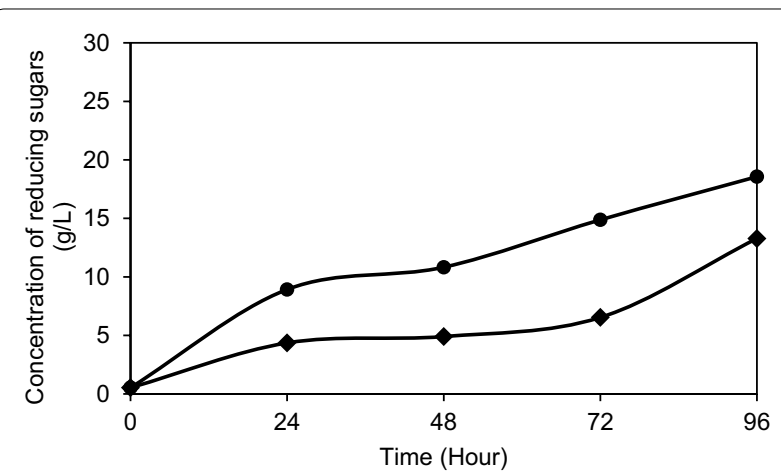

Fig. 3 Saccharification of cellulosic materials using Celluclast 1.5 L in alkaline pretreated and untreated pineapple plant stem. Symbols represent (filled circle: untreated sample, filled diamond: pretreated sample)

\section{Effects of alkali pretreatment on saccharification of cellulosic materials in pineapple plant stem}

The main purpose of alkaline pretreatment is delignification of biomass to improve its digestibility with minimal formation of inhibitory compounds, which can result in a higher yield of fermentable sugars from lignocellulosic biomass $[40,41]$. However, the result obtained from this study indicated that alkali pretreatment on the biomass has resulted in a lower concentration of reducing sugar in pineapple plant stem hydrolysate after enzymatic saccharification of the cellulosic materials, as illustrated in Fig. 3.

The concentration of fermentable sugars was higher in the untreated sample after $24 \mathrm{~h}$, and this trend continued until the end of the process. The total reducing sugars obtained after $96 \mathrm{~h}$ of saccharification in the untreated sample was recorded at $18.56 \mathrm{~g} / \mathrm{L}$, which was $5.28 \mathrm{~g} / \mathrm{L}$ higher as compared to the pretreated sample. Therefore, the untreated pineapple plant stem was used in the following step for amino acids fermentation. This result was in agreement with Casabar et al. [42], who reported a decreasing sugars production with increasing concentration of sodium hydroxide solution used in the pretreatment of pineapple peel, where sodium hydroxide concentration is inversely proportional to the sugar production in pineapple peel.

The pineapple plant stem used in this study was initially acidic, in which a low level of $\mathrm{pH}$ at 3.88 was detected. This result was in line with the acidity level in pineapple plant stem as reported by Ketnawa et al. [43], where the sample has a $\mathrm{pH}$ of 4.64 , which indicates that it consists of a high proportion of citric and malic acid. The low level of acidity might also be due to the presence of ascorbic acid, where Zaki et al. [44] has recorded $0.84 \mathrm{mg}$ of the acid present per $100 \mathrm{~mL}$ of pineapple core. Another study 
by Salomé et al. [45] also recorded a similar $\mathrm{pH}$ value of 3.85 for pineapple fruits derived from in vitro propagation plant, with $12.03 \mathrm{mg}$ ascorbic acid present per $\mathrm{g}$ fresh weight of the fruit. Since sodium hydroxide was used in the pretreatment process, the chemical might have reacted with the natural acid content present in the pineapple plant stem. The presence of inhibitory compounds and crystallinity index of the cellulose may affect sugar production in the substrate [42].

\section{Hydrolysis of starch into fermentable sugar}

About $57.57 \mathrm{~g} / \mathrm{L}$ reducing sugar was generated from the substrate which originally contained $77.78 \%$ of starch. The hydrolysis yield obtained was $100 \%$, indicating that the starch in pineapple plant stem was fully hydrolysed into fermentable sugars. This might be due to the high solubility of starch in pineapple plant stem, making it easier to be extracted and hydrolysed by the enzyme. The high starch content was in accordance with the study carried out by Nakthong et al. [8], where pineapple stem starch has reported the highest percent solubility compared to rice, corn, and cassava starches. The pineapple plant stem showed no formation of blueblack colour upon the addition of iodine solution, indicating that there was no starch left in the substrate after hydrolysis.

Gelatinisation of pineapple plant stem involves a heating process in which the starch molecules are dissolved and the viscosity increases. At high temperature, the $\alpha$-glucan chains of starch in pineapple plant stem become more susceptible to hydrolysis by amylase action due to the loss of its ordered structure [46]. Dextrozyme was chosen as the enzyme used in starch hydrolysis, because it was found to be effective in breaking down the starch granules into fine particles. It consists of glucoamylase obtained from Aspergillus niger and pullulanase from Bacillus acidopullulyticus.

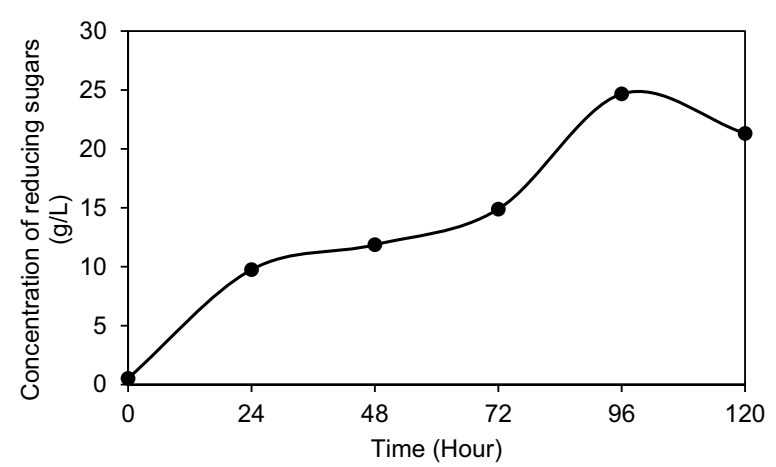

Fig. 4 Saccharification of pineapple plant stem for fermentable sugars production using Celluclast $1.5 \mathrm{~L}$
Dextrozyme was the most effective in hydrolysing corn starch when being compared with other hydrolytic enzymes, namely, bacterial $\alpha$-amylase, $\beta$-amylase and glucoamylase as reported by Ma et al. [47]. The concentration of glucose in pineapple plant stem hydrolysate was $62.91 \mathrm{~g} / \mathrm{L}$. The high amount of glucose produced indicated that starch content in pineapple plant stem is a potential carbon source to be used in fermentation for amino acids production.

\section{Saccharification of cellulosic materials into fermentable sugars}

From the result obtained in Fig. 4, the concentration of reducing sugar was the highest after $96 \mathrm{~h}$ of hydrolysis of $24.67 \pm 0.03 \mathrm{~g} / \mathrm{L}$ reducing sugars and a hydrolysis yield of $56.93 \%$, almost half the hydrolysis of starch in the pineapple plant stem. The time taken for the complete process was longer than that in the hydrolysis of starch using Dextrozyme, because the cellulosic materials have a more complex structure which require the combination of endoglucanases, exoglucanases and cellobiohydrolases for the hydrolysis process [48].

\section{Production of lysine and methionine from fermentable sugars}

The pineapple plant stem hydrolysates obtained from enzymatic hydrolysis of starch and saccharification of cellulosic materials were used as the carbon sources for the production of amino acids, namely, lysine and methionine, through microbial fermentation. Commercial glucose was used as the control in this study. To carry out microbial fermentation, $P$. acidilactici $\mathrm{Kp} 10$ was chosen as the amino acid-producing microorganism. A preliminary study of the bacteria was done prior to production fermentation to monitor the growth profiling of the bacteria.

\section{Preliminary study of Pediococcus acidilactici Kp10 used in the production of lysine and methionine}

The preliminary study aimed to evaluate the potential of P. acidilactici Kp10 in the production of amino acids, in which lysine and methionine has been done using commercial glucose as carbon source. In the production of primary metabolites, microorganisms usually produce amino acids enough only for their own needs due to feedback inhibition to prevent wasteful production $[49,50]$. Therefore, genetic manipulation of microorganisms was used to enhance the production of amino acids at higher yields [51]. This can be seen in the production of lysine and methionine using genetically modified C. glutamicum, in which the strain was capable to produce as high as $120 \mathrm{~g} / \mathrm{L}$ lysine as recorded by Becker et al. [52]. Lysine 
production can also achieve up to $170 \mathrm{~g} / \mathrm{L}$ using genetically modified strains [53]. Although the bacteria are generally recognised as safe (GRAS), the use of the genetically modified (GM) strain was not preferable in the production of feed grade lysine and methionine, in which there is a strong limitation of using the GM strain in organic farming and this has led to increasing demand of amino acids production using non-GM organisms [54].

Microorganisms generally produce 20 amino acids only in the amounts needed by the cells $[55,56]$. Therefore, the selection of strain which is able to produce an excess amount of amino acids is vital in the production of methionine and lysine. A study carried out by Lim et al. [57] showed higher production of amino acids, especially lysine and methionine, through microbial fermentation using Pediococcus sp. as compared to Lactobacillus sp. The ability of $P$. acidilactici to produce lysine and methionine was also proven by the study carried out by Toe et al. [16]. The ability of $P$. acidilactici to produce amino acids at levels beyond the needs of its metabolism without the need to genetically modified as reported by KiBeom et al. [58] has increased the potential of the bacteria to be used in the microbial fermentation of lysine and methionine production in this study.

A preliminary study of $P$. acidilactici Kp10 was done to determine the ability of the bacteria to produce lysine and methionine in the presence of glucose carbon source. Figure 5 shows the growth profiling of P. acidilactici Kp10 in MRS medium for $24 \mathrm{~h}$ incubation period.

The growth profiling of the bacteria showed the highest growth of $P$. acidilactici $\mathrm{Kp} 10$ at an optical density (OD) 1.47 after $22 \mathrm{~h}$ of fermentation. From Fig. 5, it can be observed that the bacteria have undergone lag phase at the first $3 \mathrm{~h}$, where the cell concentration only showed a slight increase. During this period, the cell

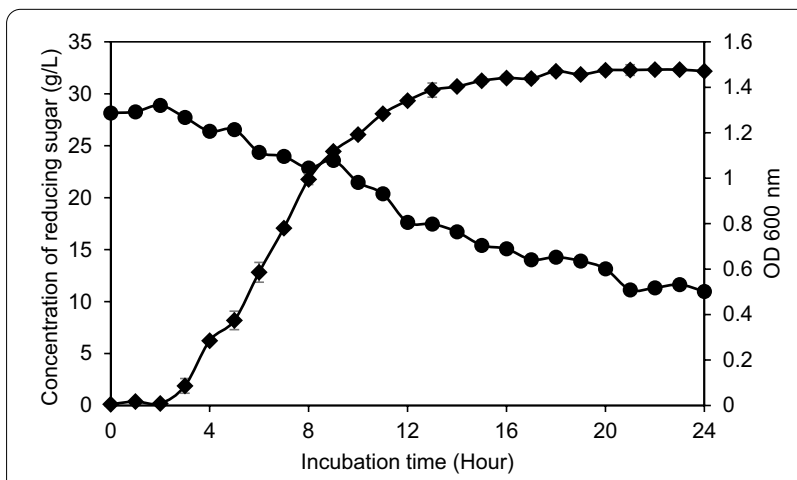

Fig. 5 Growth profiling of Pediococcus acidilactici Kp10 in MRS medium Symbols represent (filled circle: reducing sugar, filled square: $\mathrm{OD}_{600}$ ). Error bars indicate the mean value \pm standard deviation of triplicate of the sample was still adapting to the new environment and did not reproduce immediately in the medium. It was the stage, where cells are undergoing intense metabolic activity to prepare for population growth. Synthesis of enzymes and various molecules also takes place during lag phase. After $3 \mathrm{~h}$ of fermentation, the bacteria demonstrated a sharp increase in the cell concentration, indicating that the cell was undergoing exponential phase at $3 \mathrm{~h}$ to $12 \mathrm{~h}$. During the log phase, high amount of glucose was consumed for cell growth. Log phase is also known as exponential growth phase, where the cells begin to divide and grow in population. Within this phase, cells are most active metabolically and products can be produced efficiently for industrial purposes.

The bacteria then started to enter stationary phase at $12 \mathrm{~h}$, in which the rate of cell growth was equal to the rate of cell death. The exponential growth stopped during this phase, probably due to exhaustion of nutrients, accumulation of waste products and harmful changes in $\mathrm{pH}$. Once the stationary phase reached an end, the bacteria undergo death phase. In this case, the cells showed a slight decrease in cell concentration at $23 \mathrm{~h}$. During the death phase, the number of cell death generally exceed the number of new cells formed, and the condition continue until the population dies out.

Carbohydrate or sugars are the primary source of energy for microorganisms [59]. The glucose concentration present in the fermentation media demonstrated a decreasing trend, where it was continuously being consumed by the bacteria. The initial glucose concentration in the media was set at 20 and $10.98 \mathrm{~g} / \mathrm{L}$ of the carbon source was left in the medium at the end of the fermentation. This indicated that a total of $9.02 \mathrm{~g} / \mathrm{L}$ glucose was consumed within $24 \mathrm{~h}$ of the fermentation using $P$. acidilactici Kp10. Therefore, $10 \mathrm{~g} / \mathrm{L}$ glucose was used in the subsequent production medium as a carbon source for MRS media. The sugar consumption was similar to that reported by Toe et al. [16], where only $10 \mathrm{~g} / \mathrm{L}$ of reducing sugar was consumed by $P$. acidilactici UP-1, $P$. pentosaceus UP-2, and P. acidilactici UL-3.

The $\mathrm{pH}$ of the culture dropped from 5.42 to $4.34 \pm 0.03$, which was supported by Sriphochanart et al. [59] who reported a $\mathrm{pH}$ of 4.88 in the end product of microbial fermentation with initial $\mathrm{pH}$ of 6.35 using $P$. acidilactici in the presence of both lysine and methionine. The aforementioned author also claimed that the growth of the bacteria was optimum at pH 5.5-5.8, similar to the initial $\mathrm{pH}$ used in this study. Since $P$. acidilactici Kp10 is lactic acid bacteria, thus the decreased in $\mathrm{pH}$ might be caused by the production of organic acid, mainly lactic acid which is acidic $[17,60]$. 


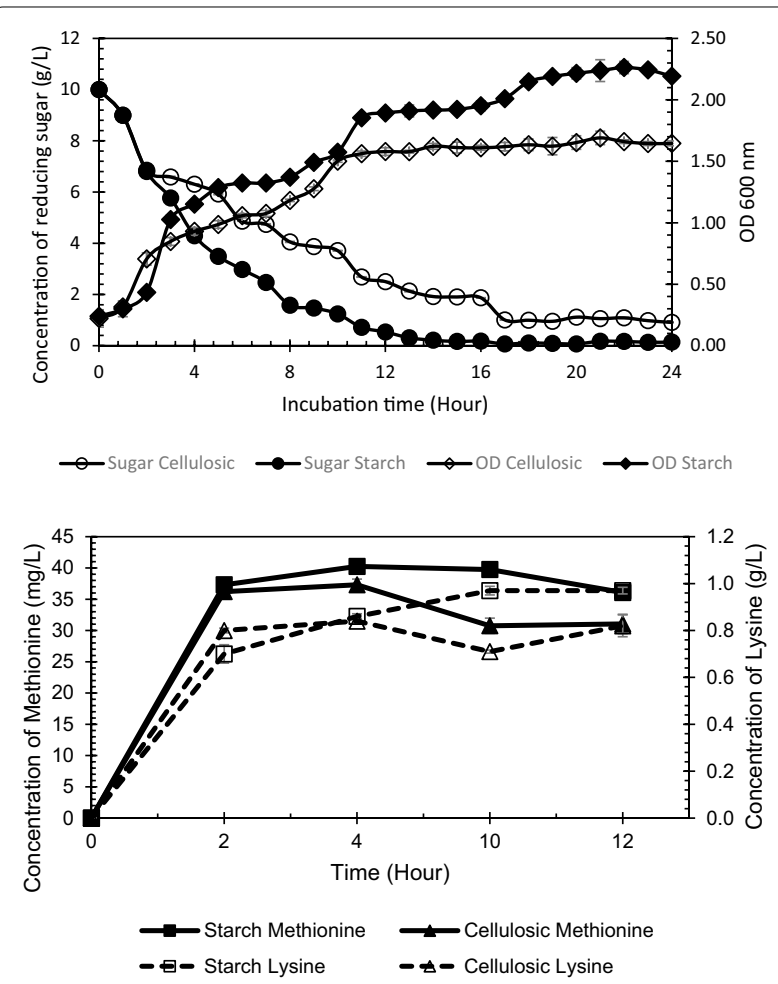

Fig. 6 Fermentation by Pediococcus acidilactici Kp10 using various carbon sources. a Growth profiling of Pediococcus acidilactici Kp10 in the mean of reducing sugar consumption and OD. $\mathbf{b}$ Amino acid production

\section{Production of amino acids using various carbon sources}

Fermentation of amino acids, especially methionine, is not always cost-efficient [55]. Carbon source plays an important role in the biosynthesis of the structural frames for amino acids and provides energy for microorganisms. Although glucose is commercially used as the carbon source in the production of amino acids, alternatives, such as the utilisation of various carbon sources from biomass, should be carried out due to its lower cost. Starch and cellulosic materials from pineapple plant stem hydrolysates have the potential to be utilised as a carbon source in the production of amino acids. The carbon source was set at $10 \mathrm{~g} / \mathrm{L}$ for all tested carbon source to get fair comparison.

Figure 6 illustrates the profiling of P. acidilactici Kp10 in the production of lysine and methionine using starch and cellulosic hydrolysate obtained from pineapple stem. The cells demonstrated a short lag phase which lasted for only $1 \mathrm{~h}$ in the production medium, followed by log phase. This indicated that the cells have a good adaptation to the new environment present in the production media, probably due to the presence of glucose as the main carbon source $[61,62]$. However, the duration of lag phase may also be affected by the number of bacteria present in the culture, where the duration for lag phase may decrease with an increasing number of cells [63]. The log phase was observed after 1-h incubation until $11 \mathrm{~h}$ of incubation. It then started to enter stationary phase before entering the death phase.

$P$. acidilactici Kp10 has the highest cell population when using starch-derived glucose as the carbon source, which has resulted in maximum $\mathrm{OD}_{600}$ of 2.26. This was followed by fermentation using commercial glucose as carbon source, with maximum $\mathrm{OD}_{600}$ of 1.86 . The cell concentration of $P$. acidilactici Kp10 was the lowest when using cellulosic materials from pineapple plant stem hydrolysate as the carbon source; however, the growth was only slightly behind fermentation using commercial glucose, where $\mathrm{OD}_{600}$ of 1.69 has been reported.

An initial of $10 \mathrm{~g} / \mathrm{L}$ sugars was provided in the fermentation medium using glucose and reducing sugars from hydrolysates as carbon sources. The remaining reducing sugars left in the fermentation medium after $24 \mathrm{~h}$ of incubation showed the amount of glucose consumed by $P$. acidilactici Kp10 for the cell to reach its maximum concentration. Highest sugar consumption was observed in starch-based fermentation, where a high value of $9.86 \mathrm{~g} / \mathrm{L}$ reducing sugars was consumed. This has resulted in the highest population of cell growth under the same condition. Sugar consumption using commercial glucose as carbon source was the lowest at $8.38 \mathrm{~g} / \mathrm{L}$, lower than using cellulosic materials from pineapple plant stem hydrolysates as carbon source, where $9.09 \mathrm{~g} / \mathrm{L}$ sugars were consumed for cell growth.

The initial carbon source in the culture medium was supplied in a low concentration of $10 \mathrm{~g} / \mathrm{L}$, enough to support the consumption for cell growth. Fermentative production of methionine usually involves $10 \%$ glucose or $5 \%$ maltose as the carbon source, in addition to other supplementation, such as inorganic salts, biotin and vitamin [53]. Using a low sugar concentration, total culture period of the strain can be reduced, with a decreased in the duration for lag phase, and in some cases will lead to an increase in amino acids yield. This is due to the formation of by-products, such as acetate and lactate, which might lead to inhibition of cell growth or reduction of production yield when a high concentration of sugar at $20 \%$, which is usually used in amino acid fermentation, is present in the medium [64]. Higher initial glucose concentration may also lead to catabolic repression effect, causing reduction of amino acids yield from 0.11 to $0.06 \mathrm{~mol} / \mathrm{mol}$ methionine with increasing glucose concentration when initial glucose concentration of $40 \mathrm{~g} / \mathrm{L}$ was used, in comparison with $20 \mathrm{~g} / \mathrm{L}$ of the glucose [65].

At $10 \mathrm{~h}$ of incubation, the cell population of $P$. acidilactici Kp10 in all conditions only showed a slight difference in which the $\mathrm{OD}_{600}$ was around 1.60 using cellulosic 
materials and 1.90 when starch was used as carbon source. During this period, the cell was almost at the end of the log phase. This result indicated that both glucose and cellulosic materials have the same efficiency as carbon sources, where the same amount of sugars was consumed to result in the same concentration of the cell population. It is interesting to mention that the cell was observed to consume more carbon source in starch hydrolysate as compared to cellulosic hydrolysate. This situation might be due to the presence of glucose in starch hydrolysate, while in cellulosic hydrolysate comprised of mixture of sugar monomers. Although microorganisms generally utilise glucose as preferred sugar during fermentation due to carbon catabolite repression, utilisation of other reducing sugars produced from saccharification of cellulosic materials was still possible [66].

P. acidilactici can be used as the amino acids producing bacteria, because it can hydrolyse the protein found in MRS medium. It can produce and accumulate proteinase in the fermentation medium, which helps in the accumulation of amino acids by hydrolysing the protein [16]. The accumulation of amino acids, including methionine and lysine, can be promoted by utilising citrulline, cysteine and glycine $[16,58]$.

Unlike secondary metabolites which are produced during stationary growth of the bacteria, known as idiophase, primary metabolites are formed during trophophase, where the products are formed at the same time as the cells grow, which causes the production curve to be parallel to the logarithmic growth phase. This phenomenon can be seen in the production of amino acids, which usually belong to primary metabolites [67]. Therefore, samples from the first $12 \mathrm{~h}$ were picked for methionine and lysine determination using HPLC, before P. acidilactici Kp10 started to enter stationary phase after $12 \mathrm{~h}$.

Increment of methionine and lysine concentration in the cell-free supernatant indicated that the cell has the ability to produce amino acids extracellularly [16]. This is important for overproducing microorganisms, whereby the accumulation of product intracellularly would require an additional downstream process for cell disruption, which is more expensive in an industrial scale. Negative side effects caused by the accumulation of intracellular accumulation of amino acids in the cytosol may also lead to decreasing production rate due to cell signalling to avoid intracellular destruction [68].

The overall production of methionine and lysine showed an increasing amount for the first $4 \mathrm{~h}$, followed by a decline in the production of the amino acids using starch and cellulosic materials as the carbon source. This result was supported by Toe et al. [16], where P. acidilactici UP-1 showed a maximum concentration of lysine production at $4 \mathrm{~h}$ of incubation. However, a different trend can be seen in the production of both amino acids when glucose was used as the carbon source up to $12 \mathrm{~h}$ of incubation, where methionine demonstrated a continuous decline in production, whereas lysine showed an increasing production. The declination of methionine in the glucose-based fermentation indicated that the amino acid was continuously utilised for the cell growth during the exponential growth of $P$. acidilactici Kp10. The bacteria have numerous nutritional requirements which include amino acids as its nitrogen source. In medium containing easily convertible nitrogen, especially amino acids, it can be stimulated to grow faster and reach higher densities [59]. The utilisation of methionine by other metabolic pathways may also lead to a decrease of methionine concentration during fermentation [65]. Low amount of amino acids may be supplied in the fermentation medium of $P$. acidilactici Kp10 which will act as the primary nitrogen source to avoid the consumption of the amino acid produced by the cell during the exponential phase. In the presence of initial amino acids as nitrogen source, the cells would be able to consume those amino acids for their growth, thus producing the required amino acids in excess. This may reduce the possibility of continuous decreased in amino acid production during the log phase of the bacteria.

Lysine was continuously produced as the cells grow, indicating that the strain was able to produce the amino acid in excess. A high amount of glucose was consumed after $4 \mathrm{~h}$ of incubation, where the cells were undergoing exponential grow. Within this period, a high amount of amino acids was produced, and the amino acids were then utilised for cell growth in the following hours. The concentrations of lysine produced in this study were comparable to starch-based glucose from cassava, sorghum, and sweet potato, with lysine production of $1.01 \mathrm{~g} / \mathrm{L}, 1.02 \mathrm{~g} / \mathrm{L}$ and $1.07 \mathrm{~g} / \mathrm{L}$, respectively, using Bacillus laterosporus as the inoculum [69].

Different carbon sources resulted in different production yield and productivity, as indicated in Table 2 . Although starch-based fermentation has the maximum cell growth and the highest amount of overall sugar consumption, it has the lowest production yield for both methionine and lysine. However, it showed higher productivity for methionine as compared to cellulosic-based fermentation. Maximum product formation and product yield were the highest for both amino acids when commercial glucose was used as the carbon source for $P$. acidilactici Kp10. The performance of cellulosic materials as the carbon source used in amino acids production was comparable to commercial glucose, especially in the production of lysine, in which the product yield was same as using glucose as carbon source. In term of productivity, 
Table 2 Comparison of methionine and lysine production by P. acidilactici Kp10 using different carbon sources

\begin{tabular}{|c|c|c|c|}
\hline \multirow[t]{2}{*}{ Parameters } & \multicolumn{3}{|c|}{ Carbon Source } \\
\hline & Glucose & Starch & Cellulosic materials \\
\hline Maximum cell growth $\left(\mathrm{OD}_{600}\right)$ & $1.86 \pm 0.02$ & $2.26 \pm 0.05$ & $1.69 \pm 0.05$ \\
\hline Overall sugar consumption (g/L) & $8.38 \pm 0.08$ & $9.86 \pm 0.01$ & $9.09 \pm 0.01$ \\
\hline \multicolumn{4}{|l|}{ Maximum product formation } \\
\hline Methionine (mg/L) & $75.50 \pm 1.41$ & $40.25 \pm 0.71$ & $37.31 \pm 0.91$ \\
\hline Lysine (g/L) & $1.61 \pm 0.13$ & $0.97 \pm 0.02$ & $0.84 \pm 0.01$ \\
\hline \multicolumn{4}{|c|}{ Incubation time for maximum production (h) } \\
\hline Methionine & 2 & 4 & 4 \\
\hline Lysine & 12 & 10 & 4 \\
\hline \multicolumn{4}{|c|}{ Substrate consumed at respected time $(\mathrm{g} / \mathrm{L})$} \\
\hline Methionine & $5.15 \pm 0.06$ & $5.71 \pm 0.07$ & $3.70 \pm 0.01$ \\
\hline Lysine & $6.98 \pm 0.00$ & $8.76 \pm 0.01$ & $3.70 \pm 0.01$ \\
\hline \multicolumn{4}{|l|}{ Maximum product yield } \\
\hline Methionine (mg/g) & 14.66 & 7.04 & 10.08 \\
\hline Lysine (g/g) & 0.23 & 0.11 & 0.23 \\
\hline \multicolumn{4}{|l|}{ Maximum productivity } \\
\hline Methionine (mg/L/h) & 37.75 & 10.06 & 9.33 \\
\hline Lysine (g/L/h) & 0.134 & 0.097 & 0.21 \\
\hline
\end{tabular}

Table 3 Comparison of methionine production by various microorganisms and carbon sources

\begin{tabular}{|c|c|c|c|c|c|c|}
\hline \multirow[t]{2}{*}{ Microorganism } & \multirow[t]{2}{*}{ Carbon source } & \multirow{2}{*}{$\begin{array}{l}\text { Initial sugar } \\
\text { concentration(g/L) }\end{array}$} & \multicolumn{3}{|l|}{ Methionine } & \multirow[t]{2}{*}{ References } \\
\hline & & & $\begin{array}{l}\text { Concentration } \\
\text { (mg/L) }\end{array}$ & Yield (mg/g) & $\begin{array}{l}\text { Productivity } \\
\text { (mg/L/h) }\end{array}$ & \\
\hline P. acidilactici Kp10 & $\begin{array}{l}\text { Starch from pineapple } \\
\text { plant stem hydro- } \\
\text { lysate }\end{array}$ & 10 & 40.25 & 7.04 & 10.06 & This study \\
\hline P. acidilactici Kp10 & $\begin{array}{l}\text { Cellulosic materials } \\
\text { from pineapple plant } \\
\text { stem hydrolysate }\end{array}$ & 10 & 37.31 & 10.08 & 9.33 & This study \\
\hline P. acidilactici Kp10 & Commercial glucose & 10 & 75.70 & 14.66 & 37.75 & This study \\
\hline Streptomyces sp. & Sucrose & 8 & 372.00 & 50.00 & 310.00 & {$[72]$} \\
\hline Lactobacillus from ogi & Glucose & 10 & $5.10^{\mathrm{a}}$ & 0.51 & 0.22 & [73] \\
\hline Yeast from ogi & Glucose & 10 & $6.60^{\mathrm{a}}$ & 0.66 & 0.23 & [73] \\
\hline Bacillus sp. & Glucose & 10 & 1200.00 & 120.00 & 50.00 & {$[74]$} \\
\hline Bacillus cereus & Glucose & 20 & 4550.00 & 60.00 & 60.00 & {$[75]$} \\
\hline P. acidilactici & Glucose & 15 & 64.70 & 4.31 & 8.09 & {$[58]$} \\
\hline Lactobacillus salivarius & Glucose & 15 & $18.6 \mathrm{~L}$ & 1.24 & 2.33 & {$[58]$} \\
\hline
\end{tabular}

${ }^{a}$ Extracellular methionine at maximum concentration

cellulosic-based glucose has resulted in the highest productivity for lysine.

The production of methionine and lysine in the fermentation using $P$. acidilactici Kp10 indicated that the strain has the ability to produce amino acids. This was supported by Lee et al. [70], who reported an increasing amount of amino acids in the fermentation by $P$. acidilactici, but a decreased in the production of methionine and lysine when L. salivarius and L. plantarum was used as the inoculum. In comparison, this study has produced a comparable methionine production with KiBeom et al. [58]. Toe et al. [16] also reported that P. acidilactici UB-6 consumed the amino acid present in the medium at the initial stage of fermentation for the cell growth, followed by maximum production of amino acids at the later stage of fermentation. 
Table 4 Comparison of lysine production by various microorganisms and carbon sources

\begin{tabular}{|c|c|c|c|c|c|c|}
\hline \multirow[t]{2}{*}{ Microorganism } & \multirow[t]{2}{*}{ Carbon source } & \multirow{2}{*}{$\begin{array}{l}\text { Initial sugar } \\
\text { concentration (g/L) }\end{array}$} & \multicolumn{3}{|l|}{ Lysine } & \multirow[t]{2}{*}{ References } \\
\hline & & & $\begin{array}{l}\text { Concentration } \\
\text { (g/L) }\end{array}$ & Yield $(g / g)$ & $\begin{array}{l}\text { Productivity } \\
\text { (g/L/h) }\end{array}$ & \\
\hline P. acidilactici Kp10 & $\begin{array}{l}\text { Starch from pineapple plant } \\
\text { stem hydrolysate }\end{array}$ & 10 & 0.97 & 0.11 & 0.10 & This study \\
\hline P. acidilactici Kp10 & $\begin{array}{l}\text { Cellulosic materials from } \\
\text { pineapple plant stem } \\
\text { hydrolysate }\end{array}$ & 10 & 0.84 & 0.23 & 0.21 & This study \\
\hline P. acidilactici Kp10 & Commercial glucose & 10 & 1.61 & 0.23 & 0.13 & This study \\
\hline C. glutamicum DM1729 & Jackfruit seed hydrolysate & 60 & 8.00 & 0.13 & 0.13 & {$[76]$} \\
\hline C. glutamicum & Corn stover ${ }^{a}$ hydrolysate & 51.6 & 14.70 & 0.29 & 0.31 & {$[77]$} \\
\hline C.glutamicum & Grass silage juice & n.d & 1.70 & 0.24 & 0.09 & {$[78]$} \\
\hline C. glutamicum & Raw corn starch & 50 & 5.28 & 0.14 & 0.22 & {$[71]$} \\
\hline C. glutamicum & Soluble starch & 50 & 6.04 & 0.16 & 0.25 & {$[71]$} \\
\hline P. acidilactici & Glucose & 15 & 0.22 & 0.014 & 0.03 & {$[58]$} \\
\hline Lactobacillus salivarius & Glucose & 15 & 0.12 & 0.008 & 0.02 & [58] \\
\hline
\end{tabular}

${ }^{a}$ Simultaneous saccharification and fermentation (SSF)

$\mathrm{g} / \mathrm{g} \mathrm{g}$ substrate/g biomass, $\mathrm{n} . d$ not determined

Production of methionine and lysine can be achieved using various carbon sources and biomass, as well as different microorganisms for fermentation. Tables 3 and 4 show the comparison of methionine and lysine production, respectively, using various microorganisms and carbon sources. Based on Table 3, the productivity of methionine using starch-based and cellulosic-based of pineapple plant stem hydrolysates produced by $P$. acidilactici Kp10 was slightly higher than the productivity of methionine using glucose as a carbon source by $P$. acidilactici as studied by KiBeom et al. [58]. For lysine production (Table 4), the productivity was the highest using cellulosic materials from pineapple plant stem hydrolysate as a carbon source. The productivity was similar to lysine production by $C$. glutamicum using raw corn starch as a carbon source as studied by Tateno et al. [71]. For starch-based fermentation from pineapple plant stem hydrolysate by $P$. acidilactici $\mathrm{Kp} 10$, the result obtained in this study was slightly higher than lysine productivity using grass silage juice as a carbon source by C. glutamicum. Lysine productivity using commercial glucose as the carbon source in this study has recorded the same value as lysine fermentation using jackfruit seed hydrolysate as a carbon source by C. glutamicum. This situation may be resulted by the composition of monomers in the hydrolysate, since the starch-based medium was mainly glucose is present, thus resulted in preference for the bacteria.

Production yields in the fermentation process may be affected by several parameters, including aeration, agitation, $\mathrm{pH}$ and temperature $[65,79]$. Distribution of the sugar and oxygen in the fermentation medium may affect the cell physiology of the inoculum, where undesirable stress response might be triggered, which is able to switch biosynthesis from the desired amino acids to undesirable by-products, such as carbon dioxide, acids, and biomass. In addition to that, the medium composition also strongly influenced the fermentation process. Natural organic substances, such as soybean hydrolysate, corn steep liquor, yeast extract or peptone, are sometimes used in lysine fermentation, with the addition of various carbon and nitrogen sources, inorganic ions and trace elements, amino acids, vitamins and numerous complex organic compounds [79].

The ability of $P$. acidilactici Kp10 to produce methionine and lysine using starch-based and cellulosic-based fermentable sugars from pineapple stem hydrolysates indicated that pineapple plant stem is potential biomass to be utilised in the production of amino acids by P. acidilactici $\mathrm{Kp} 10$. This present as an added value for the pineapple plant industry in the effort of converting waste to wealth and producing amino acids to cater the increasing needs of methionine and lysine, especially in the animal feed industry.

\section{Conclusions}

As a conclusion, pineapple plant stem is potential biomass for amino acids production due to its high starch content at $77.78 \%$. The lignocellulosic composition of pineapple plant stem consisted of $46.15 \%$ hemicellulose, $31.86 \%$ cellulose and $18.60 \%$ lignin. Starch-based hydrolysis of pineapple plant stem has resulted in $57.57 \mathrm{~g} / \mathrm{L}$ fermentable sugars. Cellulosic-based saccharification of pineapple plant stem produced $24.67 \mathrm{~g} / \mathrm{L}$ of fermentable 
sugars. Methionine and lysine were successfully produced from pineapple plant stem hydrolysates through microbial fermentation using $P$. acidilactici Kp10. Starchbased fermentation has produced $40.25 \mathrm{mg} / \mathrm{L}$ methionine and $0.97 \mathrm{~g} / \mathrm{L}$ lysine, higher than cellulosic-based fermentation, which produced $37.31 \mathrm{mg} / \mathrm{L}$ methionine and $0.84 \mathrm{~g} / \mathrm{L}$ lysine using pineapple plant stem as a substrate. This study has successfully indicated the potential of pineapple stem as feedstock in the production of lysine and methionine using microbial fermentation. The production of these amino acid can be further improved in several approaches, including the better understanding in fermentation effects as well as statistical tools utilisation.

\section{Acknowledgements}

We would like to share our heartfelt gratitude to AlafPutra Biowealth Sdn Bhd for the collaboration and supply of pineapple plant stems. This preliminary research on the starch extraction and characterisation was funded by Ministry of Higher Education, Malaysia under Fundamental Research Grant Scheme (FRGS 2020 - Characterisation of starch extracted from the pineapple plant (Ananas comosus) stem for caramel production through enzymatic hydrolysis). Finally, deep appreciation to Department of Botany, Faculty of Science, Chulalongkorn University, Thailand for the Visiting Professor attachment scheme 2020 .

\section{Authors' contributions}

PHC — data collection and data analysis. MAJ_-data collection, data analysis and interpretation, drafting the article, final approval of the version to be published. LYP and MFI_conception or design of the work, critical revision of the article. SP, WB, HP, and PL_critical revision of the article and International collaborator with corresponding author. SA-A-conception or design of the work, data analysis and interpretation, drafting the article, critical revision of the article, and final approval of the version to be published. All authors read and approved the final manuscript.

\section{Authors' information}

None.

\section{Funding}

None.

\section{Availability of data and materials}

Yes.

\section{Declarations}

Ethics approval and consent to participate

None.

\section{Consent for publication}

Not applicable.

\section{Competing interests}

None.

\section{Author details}

${ }^{1}$ Department of Bioprocess Technology, Faculty of Biotechnology and Biomolecular Sciences, Universiti Putra Malaysia, 43400 Serdang, Selangor, Malaysia. ${ }^{2}$ Department of Botany, Faculty of Science, Chulalongkorn University, Bangkok 10330, Thailand.

Received: 27 November 2020 Accepted: 26 April 2021 Published online: 16 June 2021

\section{References}

1. Campos DA, Ribeiro TB, Teixeira JA, Pastrana L, Pintado MM. Integral valorization of pineapple (Ananas comosus L.) by-products through a green chemistry approach towards added value ingredients. Foods. 2020:9(1):60. https://doi.org/10.3390/foods9010060.

2. Zainab R, Fatima M, Umma L, Zulaiha M. Pineapple waste utilization as a sustainable means of waste management. In: Zakaria Z, editor. Sustainable technologies for the management of agricultural wastes Applied environmental science and engineering for a sustainable future. Singapore: Springer; 2018. p. 143-54. https://doi.org/10.1007/978-98110-5062-6_11.

3. Zainuddin MF, Shamsudin R, Mokhtar MN, Ismail D. Physicochemical properties of pineapple plant waste fibers from the leaves and stems of different varieties. BioResources. 2014:9:5311-24.

4. Zziwa A, Jjagwe J, Kizito S, Kabenge I, Komakech AJ, Kayondo H. Nutrient recovery from pineapple waste through controlled batch and continuous vermicomposting systems. J Environ Manage. 2021. https://doi.org/10. 1016/j.jenvman.2020.111784.

5. Campos DA, Gómez-García R, Vilas-Boas AA, Madureira AR, Pintado MM Management of fruit industrial by-products - a case study on circular economy approach. Molecules. 2020;25(2):320. https://doi.org/10.3390/ molecules25020320.

6. Usmani Z, Sharma M, Awasthi AK, Sivakumar N, LukkT, Pecoraro L, Thakur VK, Roberts D, Newbold J, Gupta VK. Bioprocessing of waste biomass for sustainable product development and minimizing environmental impact. Biores Technol. 2020;16:124548. https://doi.org/10.1016/j.biort ech.2020.124548

7. Chen C, He B, Liu X, Ma X, Liu Y, Yao HY, et al. Pyrophosphate-fructose 6-phosphate 1-phosphotransferase (PFP1) regulates starch biosynthesis and seed development via heterotetramer formation in rice (Oryza sativa L). Plant Biotechnol J. 2020;18:83-95. https://doi.org/10.1111/ pbi.13173.

8. Nakthong N, Wongsagonsup R, Amornsakchai T. Characteristics and potential utilizations of starch from pineapple stem waste. Ind Crop Prod. 2017;105:74-82. https://doi.org/10.1016/j.indcrop.2017.04.048.

9. Bisinella RZB, Beninca C, Bet CD, de Oliveira CS, Demiate IM, Schnitzler E. Thermal, structural and morphological characterisation of organic rice starch after physical treatment. JTherm Anal Calorim. 2021. https://doi.org/10.1007/s10973-021-10712-7.

10. Ferla MP, Patrick WM. Bacterial methionine biosynthesis. Microbiol (United Kingdom). 2014;160:1571-84. https://doi.org/10.1099/mic.0. 077826-0.

11. Ezemba CC, Anakwenze VN, Archibong EJ, Anaukwu CG, Obi ZC, Ekwealor CC. Methionine production using native starches and proteins in submerged fermentation by Bacillus cereus s8. World J Pharm Pharm Sci. 2016;5:2056-67.

12. Sgobba E, Stumpf AK, Vortmann M, Jagmann N, Krehenbrink M, DirksHofmeister ME, et al. Synthetic Escherichia coli-Corynebacterium glutamicum consortia for L-lysine production from starch and sucrose. Bioresour Technol. 2018. https://doi.org/10.1016/j.biortech.2018.03.113.

13. Umi Kalsom MS, Ariff AB, Zulkifli HS, Tong CC, Hassan MA, Karim MIA. The treatment of oil palm empty fruit bunch fibre for subsequent use as substrate for cellulase production by Chaetomium globosum kunze. Bioresour Technol. 1997;62:1-9. https://doi.org/10.1016/S0960-8524(97)00132-6.

14. Awg-Adeni DS, Bujang KB, Hassan MA, Abd-Aziz S. Recovery of glucose from residual starch of sago hampas for bioethanol production. Biomed Res Int. 2013. https://doi.org/10.1155/2013/935852.

15. Linggang S, Yee PL, Wasoh MH, Abd-Aziz S. Sago pith residue as an alternative cheap substrate for fermentable sugars production. Appl Biochem Biotechnol. 2012;167:122-31. https://doi.org/10.1007/s12010-012-9592-0.

16. Toe CJ, Foo HL, Loh TC, Mohamad R, Abdul Rahim R, Idrus Z. Extracellular proteolytic activity and amino acid production by lactic acid bacteria isolated from Malaysian Foods. Int J Mol Sci. 2019;20:1777. https://doi. org/10.3390/ijms20071777.

17. Abbasiliasi S, Tan JS, Bashokouh F, Ibrahim TAT, Mustafa S, Vakhshiteh F, et al. In vitro assessment of Pediococcus acidilactici Kp10 for its potential use in the food industry. BMC Microbiol. 2017;17:1-11. https://doi.org/10. 1186/s12866-017-1000-z.

18. Nakamura S, Yamaguchi H, Benitani Y. Ken'lchi Ohtsubo, Development of a novel formula for estimating the amylose content of starch using japonica milled rice flours based on the iodine absorption curve. Biosci 
Biotechnol Biochem. 2020;84(11):2347-59. https://doi.org/10.1080/09168 451.2020.1794786.

19. Iwamoto S, Abe K, Yano H. The effect of hemicelluloses on wood pulp nanofibrillation and nanofiber network characteristics. Biomacromol. 2008;9:1022-6. https://doi.org/10.1021/bm701157n.

20. Leaes EX, Lima D, Miklasevicius L, Ramon AP, Pra VD, Bassaco MM, et al. Effect of ultrasound-assisted irradiation on the activities of a -amylase and amyloglucosidase. Biocatal Agric Biotechnol. 2013;2:21-5. https://doi.org/ 10.1016/j.bcab.2012.08.003

21. Tsai C-T, Meyer AS. Enzymatic cellulose hydrolysis: Enzyme reusability and visualization of $\beta$-glucosidase immobilized in calcium alginate. Molecules. 2014;19(12):19390-406. https://doi.org/10.3390/molecules191219390.

22. Paulino Rd, de Oliveira JS, Santos EM, et al. Spineless cactus use management on microbiological quality, performance, and nutritional disorders in sheep. Trop Anim Health Prod. 2021;53:168. https://doi.org/10.1007/ s11250-021-02594-6.

23. Cordenunsi B, Saura-calixto F, Diaz-rubio ME, Zuleta A, Tiné MA, Buckeridge MS, et al. Carbohydrate composition of ripe pineapple (cv. perola) and the glycemic response in humans. Food Sci. 2010;30:282-8. https:// doi.org/10.1590/S0101-20612010000100041.

24. Rani P, Tripathy PP. Modelling of moisture migration during convective drying of pineapple slice considering non-isotropic shrinkage and variable transport properties. J Food Sci Technol. 2020;57:3748-61. https:// doi.org/10.1007/s13197-020-04407-4.

25. Guiné RPF. The drying of foods and its effect on the physical-chemical, sensorial and nutritional properties. ETP Int J Food Eng. 2018;4:93-100. https://doi.org/10.18178/ijfe.4.2.93-100.

26. Kiharason JW, Isutsa DK, Ngoda PN. Effect of drying method on nutrient integrity of selected components of pumpkin (Cucurbita moschata Duch) fruit flour. ARPN J Agric Biol Sci. 2017;12:110-6.

27. Liu K. Effects of sample size, dry ashing temperature and duration on determination of ash content in algae and other biomass. Algal Res. 2019:40:101486. https://doi.org/10.1016/j.algal.2019.101486.

28. Kamalak A, Kaplan M, Kasra AA, Güven I. Effect of maturity stages on potential nutritive value, methane production and condensed tannin content of Sanguisorba minor Hay. Kafkas Univ Vet Fak Derg. 2014;20:4459. https://doi.org/10.9775/kvfd.2013.10383.

29. Gokkus A, Kahriman F, Alatürk F, Ali B. Variation of nutritional values in leaves and stalks of different maize genotypes having high protein and high oil during vegetation. Agric Agric Sci Procedia. 2016;10:18-25. https://doi.org/10.1016/j.aaspro.2016.09.004.

30. Momin RK, Kadam VB. Determination of ash values of some medicinal plants of genus Sesbania of Marathwada region in Maharashtra. J Phytol. 2011:3:52-4.

31. Hanafi MM, Selamat MM, Husni MHA, Adzemi MA. Dry matter and nutrient partitioning of selected pineapple cultivars grown on mineral and tropical peat soils. Commun Soil Sci Plant Anal. 2009;40:3263-80. https:// doi.org/10.1080/00103620903335983.

32. Koutsoukis C, Akrida-Demertzi K, Demertzis PG, Roukos C, Voidarou C, Kandrelis $\mathrm{S}$. The variation of crude protein and total fat of the main grassland plants, in various stages of growth, in "Kostilata" subalpine grassland in Theodoriana, Arta. Greece Ekin J. 2016;2(2):69-75.

33. De Santis Michele A, Giuliani M, Flagella Z, Reyneri A, Blandino M. Impact of nitrogen fertilisation strategies on the protein content, gluten composition and rheological properties of wheat for biscuit production. Field Crop Res. 2020;254:107829. https://doi.org/10.1016/j.fcr.2020.107829.

34. Bayu A, Abudula A, Guan G. Reaction pathways and selectivity in chemocatalytic conversion of biomass-derived carbohydrates to high-value chemicals: a review. Fuel Process Technol. 2019;196:106162. https://doi. org/10.1016/j.fuproc.2019.106162.

35. Sanewski GM, Bartholomew DP, Paull RE. The pineapple: botany, production and uses. 2nd ed. Boston: CABl; 2018.

36. Tako M, Tamaki Y, Teruya T, Takeda Y. The principles of starch gelatinization and retrogradation. Food Nutr Sci. 2014;05:280-91. https://doi.org/10. 4236/fns.2014.53035.

37. Liu S, Yuan TZ, Wang X, Reimer M, Isaak C, Ai Y. Behaviors of starches evaluated at high heating temperatures using a new model of Rapid Visco Analyzer-RVA 4800. Food Hydrocolloids. 2019:94:217-28. https:// doi.org/10.1016/j.foodhyd.2019.03.015.

38. Ji Z, Yu L, Liu H, Bao X, Wang Y, Chen L. Effect of pressure with shear stress on gelatinization of starches with different amylose/amylopectin ratios.
Food Hydrocolloids. 2017;1 (72):331-7. https://doi.org/10.1016/j.foodhyd. 2017.06.015.

39. Biduski B, da Silva WMF, Colussi R, El Halal SLDM, Lim LT, Dias ÁRG, da Rosa Zavareze E. Starch hydrogels: The influence of the amylose content and gelatinization method. Int J Biol Macromol. 2018;113:443-9. https://doi. org/10.1016/j.jibiomac.2018.02.144.

40. Srivastava AK, Agrawal P, Rahiman A. Pretreatment and production of bioethanol from different Lignocellulosic biomass. Int J Adv Res. 2014:2:888-96.

41. Kim JS, Lee YY, Kim TH. A review on alkaline pretreatment technology for bioconversion of lignocellulosic biomass. Bioresour Technol Elsevier Ltd. 2016;199:42-8. https://doi.org/10.1016/j.biortech.2015.08.085.

42. Casabar JT, Unpaprom Y, Ramaraj R. Fermentation of pineapple fruit peel wastes for bioethanol production. Biomass Convers Biorefinery. 2019;9:761-5. https://doi.org/10.1007/s13399-019-00436-y.

43. Ketnawa S, Chaiwut P, Rawdkuen S. Pineapple wastes: A potential source for bromelain extraction. Food Bioprod Process. 2012;90:385-91. https:// doi.org/10.1016/j.fbp.2011.12.006.

44. Zaki NA, Abd N, Ahmad N. Ascorbic acid content and proteolytic enzyme activity of microwave-dried pineapple stem and core. Chem Eng Trans. 2017;56:1369-74. https://doi.org/10.3303/CET1756229.

45. Salomé YES, Laurent KK, Irénée BJP, Patrice K, Tanoh K. Comparison of pineapple fruit characteristics of plants propagated in three different ways : by suckers, micropropagation and somatic. J Nutr Food Sci. 2011;1:1-8. https://doi.org/10.1016/j.jaci.2009.12.621.

46. Edwards $\mathrm{CH}$, Veerabahu AS, Mason AJ, Butterworth PJ, Ellis PR. a-Amylase action on starch in chickpea flour following hydrothermal processing and different drying, cooling and storage conditions. Carbohyd Polym. 2021;259:117738. https://doi.org/10.1016/j.carbpol.2021.117738.

47. Ma Y, Cai C, Wang J, Sun DW. Enzymatic hydrolysis of corn starch for producing fat mimetics. J Food Eng. 2006;73:297-303. https://doi.org/10. 1016/j.jfoodeng.2005.01.023.

48. Husin H, Ibrahim MF, Kamal Bahrin E, Abd-Aziz S. Simultaneous saccharification and fermentation of sago hampas into biobutanol by Clostridium acetobutylicum ATCC 824. Energy Sci Eng. 2019;7:66-75. https://doi.org/ 10.1002/ese3.226

49. Lin R, Liu W, Piao M, Zhu H. A review of the relationship between the gut microbiota and amino acid metabolism. Amino Acids. 2017:49(12):208390. https://doi.org/10.1007/s00726-017-2493-3.

50. Hirasawa T, Shimizu H. Recent advances in amino acid production by microbial cells. Curr Opin Biotechnol. 2016. https://doi.org/10.1016/j. copbio.2016.04.017.

51. Hanlon P, Sewalt V. GEMs: genetically engineered microorganisms and the regulatory oversight of their uses in modern food production. Crit Rev Food Sci Nutr. 2021;61 (6):959-70. https://doi.org/10.1080/10408398. 2020.1749026.

52. Becker J, Zelder O, Häfner S, Schröder H, Wittmann C. From zero to hero-Design-based systems metabolic engineering of Corynebacterium glutamicum for L-lysine production. Metab Eng. 2011;13:159-68. https:// doi.org/10.1016/j.ymben.2011.01.003.

53. Mahmood Z. Microbial amino acids production. In: Microbial Biotechnology. CRC Press; 2014. p. 187-212.

54. Willke T. Methionine production-a critical review. Appl Microbiol Biotechnol. 2014;98(24):9893-914. https://doi.org/10.1007/ s00253-014-6156-y.

55. Ivanov K, Stoimenova A, Obreshkova D, Saso L. Biotechnology in the production of pharmaceutical industry ingredients : biotechnology in the production of pharmaceutical industry ingredients : amino acids. Biotechnol Biotechnol. 2013;27:3620-6. https://doi.org/10.5504/BBEQ 2012.0134.

56. Genchi G. An overview on d-amino acids. Amino Acids. 2017;49:1521-33. https://doi.org/10.1007/s00726-017-2459-5.

57. Lim YH, Foo HL, Loh TC, Mohamad R, Abdullah N. Comparative studies of versatile extracellular proteolytic activities of lactic acid bacteria and their potential for extracellular amino acid productions as feed supplements. J Anim Sci Biotechnol. 2019;10:1-13. https://doi.org/10.1186/ s40104-019-0323-z.

58. KiBeom L, Ho-Jin K, Sang-Kyu P. Amino acids analysis during lactic acid fermentation by single strain cultures of lactobacilli and mixed culture starter made from them. Afr J Biotechnol. 2014;13:2867-73. https://doi. org/10.5897/AJB2013.13422. 
59. Sriphochanart W, Skolpap W, Scharer JM, Young MM, Douglas PL. Effect of amino acid requirements on the growth and lactic acid production of Pediococcus acidilactici culture. Adv J Microbiol Res. 2019;13:1-8. https:// doi.org/10.5897/AJMR11.721.

60. Othman M, Ariff AB, Kapri MR, Rios-Solis L, Halim M. Growth enhancement of probiotic Pediococcus acidilactici by extractive fermentation of lactic acid exploiting anion-exchange resin. Front Microbiol. 2018;9:1-11. https://doi.org/10.3389/fmicb.2018.02554.

61. Rolfe MD, Rice CJ, Lucchini S, Pin C, Thompson A, Cameron ADS, et al. Lag phase is a distinct growth phase that prepares bacteria for exponential growth and involves transient metal accumulation. J Bacteriol. 2012;194:686-701. https://doi.org/10.1128/JB.06112-11.

62. Vermeersch L, Samper GP, Cerulus B, Jariani A, Gallone B. On the duration of the microbial lag phase. Curr Genet. 2019;65:721-7. https://doi.org/10. 1007/s00294-019-00938-2.

63. Bertrand RL. Lag phase is a dynamic, organized, adaptive, and evolvable period that prepares bacteria for cell division. J Bacteriol. 2019;201:1-21. https://doi.org/10.1128/JB.00697-18.

64. Ikeda M. Amino acid production processes. Adv Biochem Eng Biotechnol. 2003:79:1-35. https://doi.org/10.1007/3-540-45989-8.

65. Zhou HY, Wu WJ, Niu K, Xu YY, Liu ZQ, Zheng YG. Enhanced L-methionine production by genetically engineered Escherichia coli through fermentation optimization. 3 Biotech. 2019;9:1-11. https://doi.org/10.1007/ s13205-019-1609-8.

66. Zhang T, Jiang D, Zhang H, Lee DJ, Zhang Z, Zhang Q, Jing Y, Zhang $Y, X i a C$. Effects of different pretreatment methods on the structural characteristics, enzymatic saccharification and photo-fermentative bio-hydrogen production performance of corn straw. Biores Technol. 2020;1(304):122999. https://doi.org/10.1016/j.biortech.2020.122999.

67. Wu Q, Zhu X, Gao H, Zhang Z, Zhu H, Duan X, et al. Comparative profiling of primary metabolites and volatile compounds in Satsuma mandarin peel after ozone treatment. Postharvest Biol Technol. 2019;153:1-12. https://doi.org/10.1016/j.postharvbio.2019.03.008.

68. Reershemius HK. Production of L-methionine with Corynebacterium glutamicum. Germany: Technical University of Braunschweig; 2008. https:// doi.org/10.24355/dbbs.084-200812050100-6.

69. Umerie SC, Ekwealor IA, Nwagbo IO. Lysine production by Bacillus laterosporus from various carbohydrates and seed meals. Bioresour Technol. 2000;75:4-7. https://doi.org/10.1016/S0960-8524(00)00052-3.

70. Lee K, Kim HJ, Park SK. Amino acids analysis during lactic acid fermentation by single strain cultures of lactobacilli and mixed culture starter made from them. Afr J Biotech. 2014;13(28):2867-73. https://doi.org/10. 5897/AJB2013.13422.
71. Tateno T, Fukuda H, Kondo A. Direct production of L-lysine from raw corn starch by Corynebacterium glutamicum secreting Streptococcus bovis a-amylase using cspB promoter and signal sequence. Appl Microbiol Biotechnol. 2007;77:533-41. https://doi.org/10.1007/s00253-007-1191-6.

72. Nwachukwu RE, Ekwealor IA. Methionine-producing Streptomyces species isolated from Southern Nigeria soil. Afr J Microbiol Res. 2009:3(9):478-81

73. Odunfa SA, Adeniran SA, Teniola OD, Nordstrom J. Evaluation of lysine and methionine production in some lactobacilli and yeasts from Ogi. Int J Food Microbiol. 2001;63(1-2):159-63. https://doi.org/10.1016/S01681605(00)00320-2.

74. Anike N, Okafor N. Secretion of methionine by microorganisms associated with Cassava fermentation. Afr J Food Agric Nutr Dev. 2008;8(1):77-90.

75. Dike KS, Obiukwu CE, Ekwealor IA. Optimization of nutritional parameters for the production of L-methionine from newly isolated Bacillus cereus strain. Microbiol Res J Int. 2014;8:1248-61. https://doi.org/10.9734/BMRJ/ 2014/2444.

76. Anusree M, Nampoothiri KM. Biosynthesis, recovery and purification of L-lysine from jackfruit seed (JFS) hydrolysate by Corynebacterium glutamicum DM 1729. Biocatal Agric Biotechnol. 2015;4(4):506-13. https://doi. org/10.1016/j.bcab.2015.08.005.

77. Chen Z, Liu G, Zhang J, Bao J. A preliminary study on L-lysine fermentation from lignocellulose feedstock and techno-economic evaluation. Biores Technol. 2019;271:196-201. https://doi.org/10.1016/j.biortech. 2018.09.098.

78. Neuner A, Wagner I, Sieker T, Ulber R, Schneider K, Peifer S, Heinzle E. Production of L-lysine on different silage juices using genetically engineered Corynebacterium glutamicum. J Biotechnol. 2013;163(2):217-24. https:// doi.org/10.1016/j.jbiotec.2012.07.190.

79. Anastassiadis S. L-lysine fermentation. B Recent Pat Biotechnol. 2007;1:1124. https://doi.org/10.2174/187220807779813947.

80. Hassan A, Othman Z, Siriphanich J. Pineapple (Ananas comosus L. Merr.). In: Postharvest biology and technology of tropical and subtropical fruits. Elsevier; 2011. p. 194-218e. https://doi.org/10.1533/9780857092618.194.

\section{Publisher's Note}

Springer Nature remains neutral with regard to jurisdictional claims in published maps and institutional affiliations.

\section{Submit your manuscript to a SpringerOpen ${ }^{\circ}$ journal and benefit from:}

- Convenient online submission

- Rigorous peer review

- Open access: articles freely available online

- High visibility within the field

- Retaining the copyright to your article

Submit your next manuscript at springeropen.com 